\title{
A Proposed Plan for Marketing the Jordanian Football League from the Perspective of Coaching and Sport Management Students at Hashemite University
}

\author{
Hasan Mohammed Al-Khaldi \\ Coaching and Sport Management Department, The Hashemite University, Zarqa, Jordan \\ Email: h_khaldi74@hotmail.com
}

Received 8 November 2015; accepted 1 February 2016; published 4 February 2016

Copyright (C) 2016 by authors and Scientific Research Publishing Inc.

This work is licensed under the Creative Commons Attribution International License (CC BY).

http://creativecommons.org/licenses/by/4.0/

C) (i) Open Access

\begin{abstract}
The purpose of this study is to examine how the students of the sport management and training department at the faculty of physical education and sport sciences at Hashemite University respond to a proposed plan for marketing the Jordanian football league. The survey based research methodology was used in this study. The researcher used a scale distributed to four dimensions: Management of the football federation, the product, distribution, and promotion. Study sample consisted of (165) male and female students representing the four academic years in the University. The results showed that there was a high level of relevance and suitability of the proposed plan for marketing the Jordanian football league. No statistically significant differences between subgroups in the sample (Academic year \& gender) were found. The researcher had recommended the authorities to provide all the incentives that helped in attracting the internal and external capital for investing in the Jordanian football industry, as well as the possibility to issue relevant sport legislations for the present stage. In addition, it was recommended to establish the needed policies that obliged the private and public sectors to support the football federation plans according to a marketing plan.
\end{abstract}

\section{Keywords}

Sport Marketing, Football League, Sport Management

How to cite this paper: Al-Khaldi, H. M. (2016). A Proposed Plan for Marketing the Jordanian Football League from the Perspective of Coaching and Sport Management Students at Hashemite University. Advances in Physical Education, 6, 1-9. http://dx.doi.org/10.4236/ape.2016.61001 


\section{Introduction}

Marketing philosophy is based on satisfying customers' current and prospected needs, attitudes, and expectation. Since the early history, human thrived to satisfy his material needs like food, clothes and shelter. So, marketing is considered as one of the oldest sciences that the human know, but the modern marketing does not only satisfy the consumers material needs and desires, rather, it is extended to include the social and psychological needs as well, and to be applied in all life aspects of products, services, policy, sport, and tourism whether locally or internationally.

The marking manager seeks to investigate and discloses the consumers' needs and the implicit and explicit desires of the different social classes, whether locally or internationally in order to satisfy them appropriately and timely.

Since the consumers needs and desires are in continuous change and development with the life development and surrounding environment, marketing seeks to disclose the unmet needs then attempting to satisfy them through the marketing mix elements (product, price, distribution and promotion, which are designed to influence consumer's decision making and lead to profitable exchanges Kotler \& Armstrong (2006). Marketing mix is a business tool that is used by the management of organizations, which enables them to remain in global competitive environment (Shankar \& Chin, 2011).

The precise plan is a clear statement with goals and objectives and it is part of a clear strategy to achieve these goals. Plans should be organized along the strategic objectives and outcomes. Also, it is considered as a comprehensive and accurate summary about the present situations. For this the marketing plan is identified as a road map for the marketing activities specific to the institution for a limited future period of time. The strategic marketing plan obviously depends on the targeted population (Wensley, 1981).

The targets, the type and level of the organizational structure, the nature of the product, and the marketing plan are all directed toward the internal and external audiences in the institution itself (Mcfarland et al., 2003).

Sport marketing function is considered as one of the most important administrative functions in the sport associations at the local, the Arab or the international level, including the Jordanian Football federation. The ability of the Jordanian Football federation to introduce a strong national team through a league that wins the local, Arab, and the international interest, will be limited unless accompanied by an active marketing effort that helps in satisfying the audiences' desires. Thereby, increasing sales and achieving the material, moral and financial profitability the association seek to achieve. Hence, the technical committee and the contest committee may be able to find a football team with superior technical level. Building the local league components in an optimal form through providing financial management and sufficient budget, may not be fruitful without the effective marketing provided by high level marketing administration, Smith (2012), Ammon et al. (2010). Marketing has been identified as a human activity that aims at satisfying the needs and the desires through the exchange process, and also identified by the American marketing association (2003) as planning, implementing and monitoring of studied activities in the product, pricing, promotion and distribution fields. Procedurally, sport marketing is identified as a comprehensive and continuous function that starts at the stage of formulating the national team, and planning the League's issues, and includes the continuous study of the internal and external audiences' needs and desires.

This process continues from the beginning of the national team participation in the Arabic, Asian or International Championships, and to follow-up on the local league to know the audiences reactions (Michael, 2010).

Marketing has been identified in the sport field as a social and administrative process through which the individuals and the groups receive their needs and desires through establishing and introducing a national team with high technical level and strong league with high reputation to everyone inside or outside the country. In addition, marketing is known as the knowledge about the communication principles and the methods of influencing and persuading others and by all means it is an art that requires the skill to use the methods and the ways in an excellent way to reach the audiences.

Hence, marketing concept in general and the sport marketing in particular is a dynamic activity, a system process, a planned, mutual, and innovative process (Smith, 2008).

This research addresses marketing the Jordanian Football League based on the modern marketing concepts using a marketing mix, which is a set of marketing tools that can be used by the institution, including the Football federation to reach its goals in the Arabic, Asian or international Football Market. Marketing mix consists of the following: 
Product: It identified as the mix of tangible and intangible features, that in any way the customer design to satisfy the public needs and desires, though establishing a football national team that is the result of a strong league, able to generate superior players should be relevant to the form and the content. It is the core of the marketing mix strategy in which retailers can offer consumers symbolic and experiential attributes to differentiate products from competitors Ferrell (2005).

Price: It is the mix of the product's features, the material and psychological features, and the services linked with them. This is represented by updating the pricing methods, selecting the prices types of discounts, and the presented prices to the audiences either to attend the games of the national team and/or the league. Price is the cost of producing, delivering and promoting the product charged by the organization Kotler (2005).

Distribution: it is any way the customer can obtain or receive a product (Jones, 2007). What is meant by the distribution is the mix of the sports buildings: the useable high quality facilities that are distributed through the kingdom either for training or for the games at the national team in summer or winter seasons, and the audiences are easily able to reach them.

Promotion: It is the mix of media processes or persuading and reminding through the marketing department communications with the external audiences. Audiences refer to the national team audience and the league audience who have the desire to follow-up the league locally or internationally. Internal audiences means all those involved in the sports field starting from those in the football federation, the quality sport associations, and through the higher levels of the sport management in the country (Smith, 2010; Slack \& Bentz, 1996).

Promotions have become a critical factor in the product marketing mix which consists of the specific blend of advertising, personal selling, sales promotion, public relations and direct marketing tools that the company uses to pursue its advertising and marketing objective (Kotler, 2005).

The importance of marketing the Jordanian Football League resides in attracting the attention of those who are in charge in the football association about the role that the marketing department should play. Despite the weakness in marketing the league and the limited financial and moral abilities allocated to the marketing processes, still the national team and the local league receive a wide interest at the regional and Arabic levels, even at the Asian level.

Marketing processes work to create positive relations based on the satisfaction between inside and outside audience about the game itself. Also, marketing the local league works to increase the sales, reaching all the individuals, and groups working in the game including the players, trainers, referees and couches as well as the clubs, thereby reaching a high level of financial income, that contributes to raise the game technically in a continuous way, and raise the level of the national team (the product) and the local league.

Sport marketing works to make the audience aware of the real level that the game has reached through the continuous communication between those in charge in the association and the audiences.

\subsection{The Problem of the Study}

Despite the continued care from people in charge, the practitioners \& the audiences of the football game in Jordan, and the difficult financial conditions the football federation is suffering from, the football national teams and the leagues are classified within the professionals league at the Asian contests level. The national team has reached an advanced level within the world cup qualifications contest to Brazil 2014, but those in charge of the football union do not have the interest or the support, also they do not allocate any budget for better performance. In addition, the researcher has noticed the lack of marketing in the football national teams and the league and that those in charge of marketing perform their work without the presence of a strategic marketing plan to reach the goals, or there are wrong practices and methods that do not correspond to what they perform to market the local league.

Through being close to the work in some Arabic Unions of the football game in which Jordanian experts are working, the researcher noticed that the league marketing procedures in these associations are fast and move from one point to another achieving great gains for the game itself.

Bill Gates, the founder of Microsoft Corporation has pointed that Marketing carries great value when it is able to provide the benefit to the consumer through improving the features of the offered product to benefit the public, the society and finally the nation.

Recent research has noted the need for reconsideration in the overall manner in which organizations practically deal with the wider process of product design (Chebbi et al., 2013; Thrassou et al., 2012). 


\subsection{Objectives}

The objectives of the study are:

1) Introduce a proposed plan for marketing the Jordanian football league.

2) Investigate the presence of statistically significant differences in the proposed plan for marketing the Jordanian Football League according to the academic year.

3). Investigate the presence of statistically significant differences in the proposed plan for marketing the Jordanian Football League according to gender variable.

\subsection{Research Questions}

The proposed research attempted to answer the following questions:

1) What is the relevance of the proposed plan for marketing the Jordanian Football League from the point of view of the students in the sport management and training department at the Faculty of Physical Education and sport sciences in the Hashemite University?

2) Are there statistically significant differences in the proposed plan for marketing the Jordanian Football League according to the academic year?

3) Are there statistically significant differences in the proposed plan for marketing the Jordanian Football League according to the gender?

\section{Methods}

The descriptive survey based research method was used in this study due to its suitability and nature of study.

\subsection{Population and Sample}

The study population consisted of the students in the management and training division in the faculty of physical educations and sport science at The Hashemite University for the year 2014-2015, which is equal to (173) students. The researcher took the whole community as a sample for the study. (173) questionnaires were distributed to all members of the study population. (165) questionnaires were recovered. Table 1 shows the distribution of the study sample and the percentages.

\subsection{Instrumentation, Validity and Reliability}

Instrument development: The researcher based on the reviewed literature on marketing developed the questionnaire. The researcher used the following tools:

1) Scale Items were determined for the proposed plan to market the Jordanian Football League through referring to the previous studies, and surveying the experts' opinion in the field of the sport management and educational management.

2) The scale Items for the proposed plan to market the Jordanian Football League were presented to experts in the sport management field and the educational management to know the extent of their relevance and suitability with the study topic.

3) Based on the experts' opinion, the researcher has changed the form and the content of some of the items that represent the scale to become in their final form as follow below.

\begin{tabular}{cccc} 
Table 1. Description of the study sample. \\
\hline Academic Year & Numbers & Average Ages & Percentage \\
\hline First & 55 & 19.02 & $33.33 \%$ \\
Second & 41 & 20.6 & $24.85 \%$ \\
Third & 39 & 21.3 & $23.64 \%$ \\
Fourth & 30 & 22.8 & $18.18 \%$ \\
Total & 165 & 20.93 & $100 \%$ \\
\hline
\end{tabular}


4) The survey has been distributed to 173 coaching and sport management students, 8 of which were identified as non-valid

\begin{tabular}{ccc}
\hline First Domain & Jordan Football Association Management & (10) Items \\
Second Domain & The National Team (the product) & (7) Items \\
Third Domain & Distribution & (11) Items \\
Fourth Domain & Promotion & (7) Items \\
\hline
\end{tabular}

\subsubsection{Instrument Validity}

The researcher based on the reviewed literature on marketing planning and sport management developed the questionnaire. The instrument validity has been confirmed through content validity by introducing the scale to the experts to make sure of the appropriateness of the used language and the extent of the items relevance to the used domain. In addition to know the extent of the belongingness of each item to the domain to which it belongs, the relevant modifications were made in the light of the experts' guidelines and suggestions.

\subsubsection{Instrument Consistency}

The scale's consistency and affirmation was made by using the internal consistency coefficients by using Grounbah-Alpah equation. The consistency values reached (0.915) which is accepted for the scientific research purposes.

\subsection{Data Analysis}

Means, standard deviations, T-test and ANOVA were used to achieve the study objectives. The research questions of the study were answered by using the relevant data in organized tables.

\section{Results and Discussion}

In light of the study questions and objectives the researcher performed the needed statistical analysis and in the order of the questions as they appeared in the study.

First, to address the question related to "what is the relevance of the proposed plan to market the Jordanian Football League from the point of view of the study sample?”.

The means and standard deviations were used and are presented in Table 2. The results show that the mean of the study sample of individuals' responses to the scale items "relevance of the proposed to the scales items" relevance of the proposed plan for marketing the Jordanian Football League as a whole (4.59 - 4.45), with standard deviation $(0.20-0.16)$. The mean of the responses to the domain items associations management was (4.45) with standard deviation (0.165), while the mean of the response to the domain item the product was (4.45) with standard deviation (0.165). The mean of the responses to the domain items of place and distribution was (4.45) and standard deviations of (0.113). Also the mean of the responses to the marketing domain promotion items was (4.47) with standard deviation (0.501), which is considered a high relevant degree for the plan to market the Jordanian Football League proposed plan.

The current study results reveal that there is a high degree of relevance of the proposed plan to market the Jordanian Football League. The researcher explains that all of the elements of the marketing process were described for the board, administrators, and couches. The role of each component is to integrate with the marketing process. On the other hand, the study sample was convincing to set the precise specification regarding the legislations of the marketing process, conducting an annual show about the Jordanian Football achievement, introducing players with high and advanced technical level to represent the Jordanian Football either at the clubs level or at the product inside and outside the country.

Cooperation between all stakeholders should be done to guarantee the live viewing of the Jordanian Football audiences whether in the league or in following up the product regarding (traffic, cars parking, security persons, ticket price). This should work as a business tool for the management of the organizations that could which enable them to remain in global competitive environment (Shankar \& Chin, 2011).

To answer the second question "Are there any statistically significant differences in the proposed structure for marketing the Jordanian Football League according to the academic year? ANOVA has been used to find the 
Table 2. Descriptive statistics of the responses of the study sample according to the proposed marketing plan $(\mathrm{N}=165)$.

\begin{tabular}{|c|c|c|}
\hline Jordan Football Association Management & The Mean & Standard Deviation \\
\hline 1 & 4.43 & 0.497 \\
\hline 2 & 4.50 & 0.502 \\
\hline 3 & 4.43 & 0.496 \\
\hline 4 & 4.41 & 0.497 \\
\hline 5 & 4.43 & 0.497 \\
\hline 6 & 4.64 & 0.500 \\
\hline 7 & 4.51 & 0.501 \\
\hline 8 & 4.46 & 0.500 \\
\hline 9 & 4.41 & 0.493 \\
\hline 10 & 4.49 & 0.502 \\
\hline Total & 4.4525 & 0.12883 \\
\hline \multicolumn{3}{|l|}{ Product } \\
\hline 1 & 4.46 & 0.502 \\
\hline 2 & 4.44 & 0.504 \\
\hline 3 & 4.42 & 0.498 \\
\hline 4 & 4.48 & 0.495 \\
\hline 5 & 4.45 & 0.501 \\
\hline 6 & 4.48 & 0.499 \\
\hline 7 & 4.45 & 0.501 \\
\hline Total & 4.4545 & 0.16563 \\
\hline \multicolumn{3}{|l|}{ Distribution } \\
\hline 1 & 4.46 & 0.500 \\
\hline 2 & 4.43 & 0.497 \\
\hline 3 & 4.44 & 0.498 \\
\hline 4 & 4.46 & 0.500 \\
\hline 5 & 4.43 & 0.496 \\
\hline 6 & 4.49 & 0.502 \\
\hline 7 & 4.45 & 0.499 \\
\hline 8 & 4.44 & .498 \\
\hline 9 & 4.47 & 0.501 \\
\hline 10 & 4.49 & 0.501 \\
\hline 11 & 4.44 & .4984 \\
\hline Total & 4.4540 & .1131 \\
\hline \multicolumn{3}{|l|}{ Promotion } \\
\hline 1 & 4.43 & .497 \\
\hline 2 & 4.48 & .501 \\
\hline 3 & 4.46 & .500 \\
\hline 4 & 4.43 & .497 \\
\hline 5 & 4.46 & .500 \\
\hline 6 & 4.47 & .501 \\
\hline 7 & 4.47 & .501 \\
\hline Total & 4.450 & .20023 \\
\hline
\end{tabular}


academic year differences. See Table 3.

The results indicate that there are no significant $(p<0.05-0.01)$ differences according to the academic year were found for the variable associations management. Referring to the results of Table 3 concerning the product, distribution, and promotion, it is clear that the F-value in each of these domains, association management, product, distribution, and promotion are $(\mathrm{F}=0.184, p=0.907)(\mathrm{F}=1.907, p=0.131)(\mathrm{F}=0.0285 p=0.836$ and $(\mathrm{F}$ $=.0 .366, p=0.777$ ) respectively. The researcher explains that the study sample individuals looked generally to the proposed plan to market the Jordanian Football League in an independent way and view it as authentic model in its applicability. On the other hand, they view it as an easy approach to establish the path through which to achieve their marketing plan. In addition, the study sample sees the proposed plan as comprehensive, integrated, continuous and targeting, since it employs the marketing process in a scientific form. The plan has also addressed the association management (that makes the decision) and the product (the league and the national team) considering it the topic of the study problem, as well as it addressed the distribution, the means and methods used to achieve the marketing process. The promotion process has been discussed, using the visual, auditory and reading media, diversification in the use method to convince the audiences to satisfy their needs and/or desires. Media, social and economic importance has naturally attracted the attention of regulators at national levels. As Kotler \& Armstrong (2006) indicated that product, price, place and promotion are designed to influence consumer decision making and lead to profitable exchanges.

To address the third question (Are there any statistically significant differences in the proposed plan for marketing the Jordanian Football League according to the gender?), T-test coefficients were used to find the differences between males and females. Table 4 shows the results

The result of the current study shows no gender differences according to the proposed marketing plan. As can be seen from the means in Table 4 of associations management $(t=.412, p=0.68)$; the product $(t=.803, p=$ $0.42)$; distribution $(t=1.545, p=0.12)$; promotion $(t=.940, p=0.35)$. It is clear that the mean of the study sample individuals responses ranged between $(4.457$ - 4.77) with standard deviation $(0.08370-0.0922)$ which expresses the absence of differences with statistical significance attributed to gender variable.

The researcher explains that the students see the proposed plan should be applied since it is integrated and comprehensive and applicable to the real life situations. Gender or experience had no effect.

\section{Conclusion}

In light of the study goals, methodology, Idata and information collected, study sample, and after discussing the study, the researcher has reached the following conclusions:

Table 3. Results of ANOVA Analysis of the responses of the study sample according to the academic year $(\mathrm{N}=165)$.

\begin{tabular}{|c|c|c|c|c|c|c|}
\hline The Domain & \multicolumn{2}{|c|}{ Total of the Squares } & \multirow{2}{*}{$\begin{array}{c}\text { df } \\
3\end{array}$} & \multirow{2}{*}{$\begin{array}{c}\text { MS } \\
0.003\end{array}$} & \multirow{2}{*}{$\begin{array}{c}\mathbf{F} \\
0.184\end{array}$} & \multirow{2}{*}{$\begin{array}{c}\boldsymbol{P} \\
0.907\end{array}$} \\
\hline & between the groups & 0.009 & & & & \\
\hline \multirow[t]{3}{*}{ Jordan Football Association Management } & within the groups & 2.630 & 156 & 0.017 & & \\
\hline & total & 2.639 & 159 & & & \\
\hline & between the groups & 0.154 & 3 & 0.051 & 1.907 & 0.131 \\
\hline \multirow[t]{3}{*}{ The product } & within the groups & 4.208 & 156 & 0.027 & & \\
\hline & total & 4.362 & 159 & & & \\
\hline & between the groups & 0.011 & 3 & 0.004 & 0.285 & 0.836 \\
\hline \multirow[t]{3}{*}{ Distribution } & within the groups & 2.0300 & 156 & 0.013 & & \\
\hline & total & 2.041 & 159 & & & \\
\hline & between the groups & 0.45 & 3 & 0.015 & 0.366 & 0.777 \\
\hline \multirow[t]{3}{*}{ Promotion } & within the groups & 6.331 & 156 & 0.041 & & \\
\hline & total & 6.376 & 159 & & & \\
\hline & between the groups & 0.007 & 3 & 0.002 & 0.321 & 0.810 \\
\hline \multirow[t]{2}{*}{ Total } & within the groups & 1.211 & 159 & 0.008 & & \\
\hline & total & 1.218 & 159 & & & \\
\hline
\end{tabular}


Table 4. Gender differences in responses to the proposed marketing plan $(\mathrm{N}=165)$.

\begin{tabular}{|c|c|c|c|c|c|c|}
\hline The Domain & Number & Mean & Stanc & lation & T-test & SIG \\
\hline \multirow{2}{*}{ Jordan Football Association Management } & Male & 73 & 4.44 & .132 & \multirow[t]{2}{*}{.412} & \multirow[t]{2}{*}{.68} \\
\hline & Female & 87 & 4.45 & .126 & & \\
\hline \multirow{2}{*}{ Product } & Male & 73 & 4.43 & .161 & \multirow[t]{2}{*}{.803} & \multirow[t]{2}{*}{.42} \\
\hline & Female & 87 & 4.46 & .168 & & \\
\hline \multirow{2}{*}{ Distribution } & Male & 73 & 4.46 & .122 & \multirow[t]{2}{*}{1.545} & \multirow[t]{2}{*}{.12} \\
\hline & Female & 87 & 4.44 & .104 & & \\
\hline \multirow{2}{*}{ Promotion } & Male & 73 & 4.43 & .222 & \multirow[t]{2}{*}{.940} & \multirow[t]{2}{*}{.35} \\
\hline & Female & 87 & 4.46 & .178 & & \\
\hline \multirow{2}{*}{ Total } & Male & 73 & 4.44 & .092 & \multirow[t]{2}{*}{1.176} & \multirow[t]{2}{*}{.24} \\
\hline & Female & 87 & 4.45 & .083 & & \\
\hline
\end{tabular}

1) There is a high degree of relevance of the proposed plan for marketing the Jordanian Football League as a whole or per the domains.

2) There are no statistically significant differences for the proposed plan to market the Jordanian Football League attributed to either the academic year or gender.

\section{Recommendations}

Based on the results from this study, the researcher has the following recommendation that he hopes the Jordanian Football association will be able to adopt:

1) Issue sport legislations concerning the possibility to promote sport marketing that is relevant to the current stage. Setting the needed procedures that oblige the public and the private sectors to support the plans of the football association according to a marketing plan.

2) Work to provide all the incentives that help in attracting the local and foreign capital for investment in the field of the Jordanian Football Industry.

3) The football association should work to activate the department of public relations and marketing departments, allocating the budget to perform their tasks according to an indorsed marketing plan.

4) The football association should work with all the specialized parties to study the audience point of view, the internal and external audience regarding the local league, and the work to satisfy these needs and desires, within the available capabilities and within a strategic plan.

The Football association should work to encourage the scientific studies and research in the marketing field from time to time that correspond with that stage.

\section{References}

Ammon, R., Southall, R. M., \& Nagel, M. S. (2010). Sport Facility Management: Organizing Events and Mitigating Risks (2nd ed.). Morgantown, WV: Fitness Information Technology.

Chebbi, H., Yahiaoui, D., Thrassou, A., \& Vrontis, D. (2013) The Exploration Activity’s Added Value into the Innovation Process. Global Business and Economics Review, 15, 265-278. http://dx.doi.org/10.1504/GBER.2013.053073

Ferrell, O. C. (2005). Marketing Strategy (3rd ed.). Mason, OH: South-Western Thomson

Jones, S. (2007). Exploring Corporate Strategy: Text \& Cases (8th ed.). Prentice Hall.

Kotler, P., \& Armstrong, G. (2006). Principles of Marketing (10th ed). New Jersey: Pearson Education Inc.

Kotler, P. (2005). Marketing: An Introduction. New Jersey: Pearson Education Inc.

McFarland, R. G., Payan, J. M., \& Bloodgood, J. M. (2003). Chain Reaction Behaviors in Channels of Distribution. Enhancing Knowledge Development in Marketing, 14, 221-222.

Michael, L. (2010). Marketing: Defined, Explained, Applied. Upper Saddle River, NJ: Pearson Prentice Hall.

Shankar. C., \& Chin, K. (2011). A Study of the Relationship between Marketing Mix and Customer Retention for Herbal Coffee in Malaysia. Proceedings of 2nd International Conference on Business and Economic Research (2nd ICBER, 2011), Proceeding (No. 2011-279). 
Slack, T., \& Bentz, L. (1996). The Involvement of Small Businesses in Sport Sponsorship. Managing Leisure, 1, $175-184$. http://dx.doi.org/10.1080/136067196376410

Smith, A. (2012). Introduction to Sport Marketing. New York, NY: Routledge.

Smith, A. (2008) Introduction to Sport Marketing. Oxford: Elsevier Butterworth Heinemann

Wensley, R. (1981). Strategic Marketing: Betas, Boxes, or Basics. Journal of Marketing, 45, 173-182. http://dx.doi.org/10.2307/1251551

Thrassou, A., Vrontis, D., Chebbi, H., \& Yahiaoui, D. (2012). A Preliminary Strategic Marketing Framework for New Product Development. Journal of Transnational Management, 17, 21-44. http://dx.doi.org/10.1080/15475778.2012.650108 